\title{
Anna Zaborowska
}

\section{Statek jako peculium w rzymskim prawie klasycznym}

Rozwój gospodarczy Rzymu doprowadził do zmian w przewozie

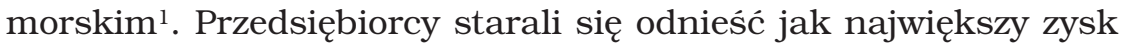
przy jak najmniejszym ryzyku², to zaś było możliwe, gdy prowadzili statek samodzielnie lub gdy wyznaczali osobę godną zaufania i mającą szerokie kompetencje. Na ogół właściciel statku jako exercitor navis powierzał swój okręt (res dominica) niewolnikowi na podstawie praepositio, ustanawiając go kapitanem (magister navis) ${ }^{3}$. Upowszechnienie się peculium w gospodarce rolnej i handlu lądowym mogło skłonić armatorów do szukania rozwiązań oferujących korzystniejsze rozwiązania ekonomiczne. W materiale źródłowym znajdują się informacje, że servus peculiaris mógł pełnić rolę arma-

1 Szerzej na temat transportu morskiego w starożytności zob. np.: L. Casson, Ships and seamanship in the ancient world, Princeton New Jersey 1973, s. 145 i n., 156 i n., 164 i n., 206 i n., 213 i n.; O. Höckmann, Antike Seefahrt, München 1985, s. 37 i n., 52 i n., 136 i n.; L. Casson, The Ancient Mariners. Seafarers and Sea Fighters of the Mediterranean in Ancient Times, Princeton New Jersey 1991, s. 184 i n.; S. Ducin, Sztuka nawigacji $w$ starożytnej Grecji i Rzymie, Lublin 1997, s. 12 i n., 79 i n.; J. Krzynówek, Odpowiedzialność przedsiębiorcy (exercitor) w prawie rzymskim, Warszawa 2000, s. 199.

2 Jak pisze Stanisław Ducin, Rzymian do żeglugi popchnęła konieczność, możliwość podboju nowych terytoriów i chęć zysku $z$ handlu $z$ nowymi krajami, a nie, jak w przypadku Greków czy Fenicjan, miłość do morza (op.cit., s. 50 i n.).

3 Zob. G.4,69-74. 
tora ${ }^{4}$ Czy oznaczało to, że osoba prowadząca morską działalność gospodarczą przekazywała całe negotiatio w ręce niewolnika jako peculium?

\section{Statek jako przedmiot działalności handlowej}

Jak pisał Lucius Iunius Modestinus Columella, żeglowanie stało się źródłem zysków:

Columella, De re rustica, 12,2

Si quidem vel rusticari, vel navigari, vel etiam genere alio negotiari necesse erat, ut aliquas facultates acquireremus.

Columella pisał, że navigare jest formą negotiatio ${ }^{5}$. Żegluga (navigare $)^{6}$ wzmiankowana w źródle to nie podróż okrętem, ale taka forma aktywności morskiej, która przynosi korzyści finansowe (facultates). Podstawą rozwoju gospodarczego Rzymu była uprawa roli (rusticare). Jednakże - jak pisze Columella - żegluga stała się kolejną obok rolnictwa działalnością gospodarczą, w którą Rzymianie angażowali swój kapitał w celu osiągania dochodów. Statek, służąc do przewozu towarów i osób, był traktowany jako przynosząca zysk działalność handlowa (negotiatio).

\footnotetext{
${ }^{4}$ W zakresie zarządu statkiem można wyróżnić dwie formy powierzania działalności gospodarczej: dwupoziomową (dominus (exercitor navis) - magister navis) oraz trójpoziomową (dominus - exercitor navis (servus peculiaris) magister navis). Szerzej na ten temat zob.: A. Földi, Remarks on the legal structure of eneterprises in Roman law, RIDA 43, 1996, s. 179-211; A. Zaborowska, Typy wewnętrznych struktur podmiotowych działalności handlowej zwiazzanej $z$ powierzaniem statku niewolnikowi $w$ rzymskim prawie klasycznym, [w:] Toruńskie studia polsko-włoskie (Studi Polacco-Italiani di Toruń), t. V, Z. Witkowski, C. Bronowski (red.), Toruń 2009, s. 33-47.

5 Negotio oznacza 'prowadzić interesy', 'handlować', 'ciągnąć zyski'. Zob. A. Berger, Encyclopedic Dictionary of Roman Law, Philadelphia 1953, s.v. negotiari; J. Sondel, Słownik łacińsko-polski dla prawników i historyków, Kraków 1997, s.v. negotior.

6 Navigare oznacza 'żeglować', 'puszczać się na morze’, 'płynąć statkiem', 'ciągnąć zyski z żeglugi'. Zob. A. Berger, op.cit., s.v. navigare.
} 
Negotiatio to interesy handlowe, działalność handlowa, ale też zakład handlowy, na którym te interesy się opierały ${ }^{7}$. Jak pisze Jerzy Krzynówek ${ }^{8}$, negotiatio to zakład handlowy powierzony institorowi, którego prowadzenie polega na zawieraniu umów emptiovenditio lub locatio-conductio, zatem jest to działalność ciągła prowadzona w celu osiągania zysku, autonomiczna pod względem majątkowym od majątku powierzającego. Negotiatio rozumiana jest więc jako zespół czynników, dzięki którym można prowadzić określoną działalność handlową. Przykładami negotiatio mogą być taberna ${ }^{9}$, caupona ${ }^{10}$ czy mensa ${ }^{11}$. W przypadku działalności morskiej statek, służąc do przewozu towarów i osób na podstawie umów transportowych (locatio-conductio), traktowany był jako negotiatio.

W źródłach prawnych pojawiają się zarówno terminy oznaczające środek transportu (navis ${ }^{12}$, navicula ${ }^{13}$, navigium ${ }^{14}$ ), jak i nazwy poszczegółnych typów okrętów w zależności od konstrukcji (np. ratis $^{15}$, lyntarium ${ }^{16}$, scapha ${ }^{17}$ ) czy przeznaczenia ${ }^{18}$ (actuaria, navis

7 Zob.: A. Berger, op.cit., s.v. negotiatio, s.v. negotium; W. Wołodkiewicz (red.), Prawo rzymskie. Słownik encyklopedyczny, Warszawa 1986, s.v. negotium; J. Sondel, op.cit., s.v. negotiatio, s.v. negotium.

8 Zob. J. Krzynówek, op.cit., s. 189-198.

9 D. 14,3,18 (Paulus), D.15,1,47pr.; D.50,16, 185 (Ulpianus).

10 D.33, 1, 13 (Paulus).

11 D.2,13,6,3 (Ulpianus).

12 Zob. D.14,1 passim; D.14,2 passim; D.4,9 passim; D.9,4 passim.

13 Zob. D.21,2,44 (Alfenus); P.S. 3,6,66.

14 Zob. D.43,12, 1 (Ulpianus).

15 Zob. D.47,9,4, 1 (Paulus); D.4,9,1,4 (Ulpianus); D.43, 14,1pr. (Ulpianus).

16 Zob. D.21,2,44 (Alfenus); D.33,7,29 (Labeo); D.6,1,3,1 (Ulpianus).

17 Zob. D.49, 15,2 (Marcellus); D. 14,1,1,12 (Ulpianus).

18 W źródłach znajdują się informacje o różnych typach statków szczególnie istotnym przykładem jest wypowiedź Ulpianusa (D. 14,1,1,12). Jak wynika $z$ tego fragmentu, istniały statki służące do transportu towarów (navis oneraria), którymi przewożono także ludzi. Statek mógł służyć do transportu tylko pasażerów lub tylko towarów, a nawet tylko do konkretnego typu towaru. Jak pisał Ulpianus, jeżeli kapitan został ustanowiony do transportu danego typu towaru, to znaczyło to, że albo statek nie nadawał się do przewozu innych surowców, albo że dany przewoźnik zajmował się tylko jedną określoną formą przewozu. W przypadku navis oneraria, ze 
oneraria, navis longa ${ }^{19}$ ). Spośród nich navis jest najbardziej ogólnym określeniem statku. Definicję statku podał Ulpianus:

Ulpianus libro vicensimo octavo ad edictum (D.14,1,1,6)

Navem accipere debemus sive marinam sive fluviatilem sive in aliquo stagno naviget sive schedia sit.

Jak wynika ze źródła, navis to statek pływający po morzach, rzekach bądź jeziorach albo tratwa. Definicja podana przez Ulpianusa jest bardzo szeroka, obejmuje bowiem każdy typ statku, bez względu na akwen, po którym się porusza. $Z$ jednej strony nazwą

względu na bardzo dużą pojemność tego typu statku, transportowano zarówno ludzi, jak i towary. W przypadku mniejszych jednostek lub krótkich tras statek mógł służyć wyłącznie do przewozu osób. Z informacji ze źródła wynika, że o ustanowieniu kapitana do danych czynności decydował właściciel. Można więc założyć, że miał on możliwość wyboru prowadzonych usług i sam decydował o ich zakresie, co umożliwiało swobodną specjalizację prowadzonej działalności handlowej. W sytuacji opisanej przez Ulpianusa forma negotietur oznacza prowadzenie działalności morskiej polegającej na wykonywaniu usług transportowych. Z tekstu wynika, że przewozów dokonywano na określonych trasach lub na określonych obszarach. To może świadczyć o pewnej powtarzalności wykonywania takich usług. Z tego zaś wynikałoby, że dany przewoźnik podejmował się przewozu danego typu towaru bądź ludzi na określonym szlaku, co świadczyłoby o specjalizacji przewozów. To zaś pociągałoby założenie, że transport taki mógł być systematyczny, jak na warunki ówczesnej żeglugi, taką opinię wyraża też G. Houston (zob. idem, The administration of Italian Seaports during the first three centuries of the Roman Empire Trade, [w:] J.H. D'Arms, E.Ch. Kopff, The seaborn Commerce of Ancient Rome: Studies in Archaelogy and History, Rome 1980, s. 157 i n.). Stanisław Ducin, opierając swe badania na źródłach pozaprawnych, podaje, że w starożytności istniały stałe trasy żeglugowe oraz sezony, w których intensywność ruchu morskiego rosła bądź malała. Brundisium i Dyrrachium, o których pisze Ulpianus, były zdaniem S. Ducina jednymi z większych portów tamtego okresu, będąc jednocześnie wielkimi ośrodkami handlowymi. Zob. S. Ducin, op.cit., s. 59 i n. Szerzej na temat transportu i portów zob. O. Höckmann, op.cit., s. 52 i n., 142 i n.; L. Casson, Ships and seamanship in the ancient world, Princeton New Jersey 1973, s. 10 i n.; G. Houston, op.cit., s. 157 i n.; http://www.ostia-antica.org (dostęp: 3.12.2009).

19 Te trzy typy statków wymienia Marcellus (D.49,15,2). 
navis Ulpianus obejmuje wszystkie statki, bez względu na wody, po których się poruszają, $z$ drugiej stony, dodając do tego wyliczenia tratwę (schedia), wskazuje na konstrukcję środka transportu. Francesco De Martino uważa, że słowo schedia jest pochodzenia greckiego i prawdopodobnie nie zostało użyte przez Ulpianusa tylko nastąpiła tu ingerencja kompilatorów, zwłaszcza że Ulpianus nie odniósł się do edyktu, ograniczając wypowiedź do zagadnienia statków $^{20}$. Zdaniem J. Krzynówka ${ }^{21}$ słowa sive schedia sit nie pasują do całości wywodu Ulpianusa, gdyż wprowadzają dodatkowe kryterium $\mathrm{w}$ sposób nieharmonizujacy $\mathrm{z}$ początkiem wypowiedzi. W opinii tego autora Ulpianus na początku swego wywodu jako kryterium skorzystania $\mathrm{z}$ actio exercitoria stosuje typy akwenów, a nie rodzaje łodzi ${ }^{22}$. Po danym akwenie pływały statki o różnej konstrukcji, czego Ulpianus nie rozróżnia, zaliczając do navis wszelkie środki transportu, bez względu na budowę, uwzględniając samo tylko miejsce poruszania się statków. Wprowadzenie do definicji słowa „tratwa” powoduje ocenę statków ze względu na ich konstrukcję, mimo że w początkowej wypowiedzi takiego podziału nie ma. Myślę, że można założyć, iż dołączenie słów sive schedia sit jest skutkiem ingerencji późniejszych prawników, ale może być też wynikiem zmian zachodzących w rozwoju gospodarki transportowej, pojawienia się nowych typów statków i w związku $z$ tym różnych regulacji prawnych, odzwierciedleniem czego może być wielość nazw statków w źródłach i różne ich ujmowanie w prawie, jak na przykład przy odpowiedzialności z receptum nautarum ${ }^{23}$.

20 Autor ten jest zdania, że słowo schedia jest transkrypcją słowa grec-

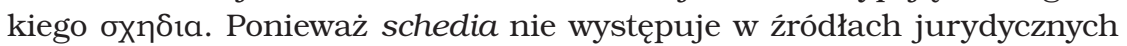
współczesnych Ulpianusowi, F. De Martino zakłada, że zmiana pochodzi od kompilatorów justyniańskich. Jego zdaniem także stagno jest interpolowane, gdyż stylistycznie nie łączy się prawidłowo z początkiem zdania. Zob. F. De Martino, Navis, eadem navis - specificatio, Dritto privato e societa a roma, [w:] Scritti di dritto romano II, Roma 1982, s. 47-48.

21 Autor ten uważa, że miała tu miejsce ingerencja poklasyczna i nastąpiło dodanie słów sive schedia sit. Zob. J. Krzynówek, op.cit., s. 172.

22 Ibidem.

23 D. 4,9,1,4 (Ulpianus). 


\section{Powierzenie statku niewolnikowi w ramach peculium}

Jeżeli statek byłby peculium, to musiałby mieć te same cechy, którymi charakteryzował się ten typ majątku. To znaczy, że musiałby być dzierżony przez niewolnika (habere), działalność morska musiałaby być prowadzona za zgodą właściciela statku (permissus domini) i być oddzielona pod względem majątkowym i rachunkowym od patrimonium (separatum a rationibus dominicis) ${ }^{24}$. Jeżeli statek należał do peculium, to czy był jego częścią, czy stanowił całe odrębne peculium?

Poniższa wypowiedź Paulusa dotyczy statku zarządzanego przez niewolnika:

Paulus libro vicensimo secundo ad edictum (D.9,4,19,2)

Si servus tuus navem exercuerit eiusque vicarius et idem nauta in eadem nave damnum dederit, perinde in te actio danda est ac si is exercitor liber et hic vicarius servus eius esset, ut de peculio servi tui ad noxam dedere vicarium damneris: ut tamen, si servi tui iussu vel sciente et patiente eo damnum vicarius dederit, noxalis actio servi tui nomine esse debeat. idemque sit etiam, si nautam facere iusserit.

Paulus rozważał kwestię odpowiedzialności $z$ tytułu damnum iniuria datum. $Z$ przedstawionej przez jurystę sytuacji wynika, że statkiem zarządzał niewolnik. Na początku wypowiedzi pojawił się zwrot servus tuus, a w dalszej części zdania określenie de peculio servi tui, które odnosiło się do tego samego niewolnika. Wynika $\mathrm{z}$ tego, że zarządca statku to servus peculiaris. Paulus podał, że servus vicarius to niewolnik zarządcy statku (servus tuus [...] eiusque vicarius). Skoro servus vicarius to taki niewolnik, który znajdował się $\mathrm{w}$ peculium innego niewolnika, to w tym przypadku znajdował się w peculium niewolnika zarządzającego statkiem.

24 Jak wynika $\mathrm{z}$ definicji peculium - D.15,1,5,4 (Ulpianus). Zob. J.-J. Aubert, Business managers in ancient Rome: a social and economic study of Institores 200 B.C - A.D. 250, Leiden 1994, s. 95-100; J. Krzynówek, op.cit., s. 194-198. 
Servus vicarius, o którym pisał Paulus, był jednocześnie żeglarzem, a za szkodę wyrządzoną przez niego na statku (in nave) właściciel mógł wydać go noksalnie $z$ peculium zarządcy ${ }^{25}$. Servus peculiaris zarządzał statkiem, a jego servus vicarius pełnił na tym samym statku funkcję żeglarza. Obaj niewolnicy powiązani byli zarówno zależnościami ekonomicznymi wynikającymi z peculium, jak i byli zaangażowani w tę samą działalność przewozową.

Niewolnika zajmującego się statkiem dotyczy też wypowiedź Ulpianusa:

Ulpianus libro vicensimo octavo ad edictum (D.14,1,1,22)

Si tamen servus peculiaris volente filio familias in cuius peculio erat, vel servo vicarius eius navem exercuit, pater dominusue, qui voluntatem non accommodauit, dumtaxat de peculio tenebitur, sed filius ipse in solidum. plane si voluntate domini vel patris exerceant, in solidum tenebitur et praeterea et filius, si et ipse voluntatem accommodauit, in solidum erit obligatus.

Z tej wypowiedzi wynika, że servus peculiaris, za wolą filius familias, lub jego servus vicarius, za wolą servus peculiaris, zarządzał statkiem. Ojciec lub właściciel, który nie wyraził zezwolenia na zarządzanie statkiem przez niewolnika, był odpowiedzialny tylko de peculio. Natomiast jeżeli niewolnik zarządzał statkiem za wolą właściciela, to zwierzchnik był odpowiedzialny in solidum. Filius familias powierzający prowadzenie działalności gospodarczej był odpowiedzialny in solidum.

W źródle wyraźnie występuje powiązanie między peculium a statkiem. Servus peculiaris był zarówno częścią peculium zarządzanego przez syna, jak i sam dysponował własnym peculium ${ }^{26}$. Francesco

25 Miejsce wyrządzenia szkody ma wpływ na zakres odpowiedzialności, bowiem exercitor nie odpowiada za czyny żeglarzy poza statkiem. Zob. D.4,9,7 pr. (Ulpianus).

26 Zdaniem F. De Martino (Studi sull' actio exercitoria, Rivista del dritto della navigazione, 7, 1 [1941] (= Dritto privato e societa' romana, Scritti di dritto romano II. Diritto e societa' nel' antica Roma, a cura di Alberto dell' Agli e Tullio Spagnuolo Vigorita, Roma 1982), s. 164 i n.) servus peculiaris był niewolnikiem będącym częścią peculium, który sam nie dysponował 
De Martino uważa, że zarządzanie statkiem powierzano niewolnikowi znajdującemu się $\mathrm{w}$ peculium syna ${ }^{27}$. Armatorem był więc servus peculiaris lub servus vicarius, a odpowiedzialność właściciela powstawała wskutek umów zawieranych przez osoby trzecie $z$ kapitanem danego niewolnika. Podobnego zdania są G. Pugliese ${ }^{28}$, G. Longo ${ }^{29}$ i A. Földi ${ }^{30}$. Ponadto w źródle mowa jest o odpowiedzialności in solidum bądź de peculio, w zależności od zezwolenia właściciela. W takim razie statek musiał być częścią peculium. Pojawia się jednak pytanie: w którym majątku znajdował się statek, w tym należącym do filius familias czy w tym, którym dysponuje servus ordinarius?

Zgodnie $\mathrm{z}$ definicją Tubero ${ }^{31}$ elementem niezbędnym dla istnienia peculium był permissus domini. Przy czym permissus domini z tej definicji dotyczył dzierżenia peculium, Ulpianus w powyższej wypowiedzi odniósł voluntas do zarządu statkiem. Niewolnik mógł zarządzać majątkiem, który faktycznie uzyskał, co oznaczało, że oprócz werbalnego zezwolenia na prowadzenie działalności musiało nastąpić rzeczywiste przekazanie rzeczy mających być składnikami peculium. Myślę, że w przypadku statku było podobnie - niewolnik, aby mógł zarządzać statkiem, musiał go fizycznie uzyskać od swojego bezpośredniego zwierzchnika (filius familias) bądź od właści-

takim majątkiem. Natomiast W.W. Buckland (Roman Law of Slavery, Cambrigde 1908, s. 175), G. Pugliese (In tema di „actio exercitoria”, Labeo 3 [1957], s. 308 i n.), S. Solazzi (L'etá dell' actio exercitoria, Rivista del dritto della navigazione 1941, s. 185-212 (= Scritti di dritto romano, IV, Napoli 1963, s. 243-264)), G. Longo (Actio exercitoria, actio institoria, actio quasi institoria, [w:] Studi in onore di G. Scherillo, II, Milano 1972, s. 581 i n.), J.-J. Aubert (op.cit., s. 62 i n.) czy A. Földi (La responsabilita dell'armatore potesta per atti compiuti dell 'exercitor' suo sottoposto', SDHI 64, 1998, s. 179 i n.) sądzą, że wskazany tu servus peculiaris to niewolnik, który mógł zarządzać peculium. Skłaniam się ku opinii większości tych badaczy, że omawiany niewolnik mógł dzierżyć peculium.

27 F. De Martino, op.cit., s. 164 i n.

28 G. Pugliese, op.cit., s. 308 i n.

29 G. Longo, op.cit., s. 581 i n.

30 A. Földi, op.cit., s. 179 i n.

31 D. 15, 1,5,4 (Ulpianus). 
ciela. Sądzę, że J.-J. Aubert ${ }^{32}$ trafnie zauważył, że permissus jest pojęciem zbliżonym do voluntas, dotyczy bowiem subiektywnego odczucia właściciela. Permissus domini jest wyrażeniem woli tak samo jak voluntas. Można więc założyć, że zezwolenie właściciela dotyczące exercitio navis obejmowało też pozwolenie na dzierżenie statku jako peculium.

Servus peculiaris mógł zarządzać majątkiem powierzonym mu przez właściciela w ramach peculium, a czynności, których dokonywał, powinny dotyczyć peculium. Ulpianus pisał, że servus vicarus mógł zarządzać statkiem za niewolnika, w którego majątku się znajdował. Celsus, powołując się na Tubero, pisał, że servus peculiaris mógł powierzyć peculium swojemu servus vicarius ${ }^{33}$. Skoro mógł też powierzyć zarząd nad statkiem, to okręt musiał być częścią peculium. Gdyby statek nie był częścią peculium, wola servus peculiaris nie miałaby żadnego znaczenia, gdyż istotne było tylko zezwolenie tej osoby, w której majątku znajdował się statek. Dlatego uważam, że gdy Ulpianus pisał, iż servus peculiaris [...] navem exercuit, to oznaczało to, że statek znajdował się w peculium niewolnika ${ }^{34}$.

Myślę, że niewolnikowi zarządzającemu peculium powierzano działalność handlową, która mogła odbywać się w ramach peculium, zwłaszcza gdy dotyczyła sfery tak istotnej gospodarczo jak transport morski. Jak wynika ze źródeł, servus peculiaris mógł prowadzić działalność gospodarczą, którą powierzył mu dominus. Mógł też trudnić się kilkoma zajęciami jednocześnie. Wydaje mi się możliwe zarówno to, że niewolnik zajmował się wyłącznie transportem morskim, i wtedy okręt stanowił całe odrębne peculium, jak i to, że niewolnik trudniący się kilkoma zajęciami handlowymi jednocześnie

32 Jak pisze J.-J. Aubert (op.cit., s. 45, 196-198), permissus to voluntas pana w zakresie czynności niewolnika; tak jak brano pod uwagę voluntas, gdy ustanowiany był institor, tak istotny był permissus domini, gdy ustanowiany jest dispensator. W zbliżonym znaczeniu permissus domini występuje w źródłach: D. 15, 1,5,4 (Ulpianus) i D. 14,1,1,20 (Ulpianus).

33 D. 15, 1,6 (Celsus).

34 Problematyka statku jako peculium poruszana jest także w tych źródłach: D. 14,1,6 pr. (Paulus); D.47,2,42 pr. (Paulus), D.4,9,3,3 (Ulpianus); D.4,9,7,6 (Ulpianus); D. 14,1,1,20 (Ulpianus); D. 14,1,4,4 (Ulpianus). 
zarządzał peculium, którego tylko częścią był statek. Statek mógłby być częścią peculium także wtedy, gdyby niewolnik zajmował się wyłącznie exerctio navis, ale oprócz statku uzyskał inne przedmioty, niekoniecznie przeznaczone do prowadzenia działalności handlowej. Z tego względu statek mógł być częścią bądź całością peculium.

W źródłach nie znalazłam informacji, co działo się ze statkiem będącym częścią peculium, gdy niewolnik zarządzający nim zmarł. Zakładam jednak, że tak jak zwykłe peculium majątek taki zmieniał status i był traktowany jako majątek właściciela, a nie jako wyodrębniona jednostka majątkowa. Chodzi mi oczywiście o aspekt techniczny i formalne zakwalifikowanie takiej masy majątkowej jako peculium bądź patrimonium. Nie zaś o aspekt prawny, gdyż z punktu prawnego właścicielem peculium cały czas był dominus. Sądzę więc, iż należy przyjąć, że zgon niewolnika powodował wygaśnięcie peculium, majątek ten stawał się częścią patrimonium ${ }^{35}$. Ponieważ do działalności morskiej prowadzonej przez niewolnika stosowano wiele zasad charakterystycznych dla zwykłego peculium, to uważam, że również w tym przypadku należy odwołać się do tych generalnych reguł. Zatem śmierć zarządcy statku powodowała, że przedsiębiorstwo morskie prowadzone przez niewolnika traciło charakter wyodrębnionego majątku i było traktowane jako res dominica.

\section{Rozliczenia związane z działalnością statku}

Jednym $\mathrm{z}$ wymogów istnienia peculium było wyodrębnienie majątkowe peculium od patrimonium i istnienie oddzielnych rachunków. Wiązało się to $z$ odrębnymi wpływami uzyskiwanymi przez niewolnika $z$ zarządu peculium. W źródłach nie ma informacji o rachunkach dotyczących statku, są za to informacje dotyczące zysków. O wpływach z zarządu statkiem pisał Gaius w swych Instytucjach:

35 Zob. D. 15,2,3 (Pomponius); D. 15,3,3, 1 (Ulpianus). Zob. W.W. Buckland, op.cit., s. 227. 
G. 4,71 :

Ideo autem exercitoria actio appellatur, quia exercitor vocatur is, ad quem cotidianus navis quaestus pervenit.

Gaius użył określenia quaestus. Rzeczownik ten oznacza 'zysk', 'zarobek', 'zbiory', 'sposób zarobkowania', 'dochód'36. Quaestus to ogólne pojęcie dotyczące korzyści wynikającej z prowadzonej działalności gospodarczej i oznacza stały dochód uzyskiwany $z$ wykonywanego zajęcia. Exercitor navis jest tą osobą, do której trafiają dochody uzyskiwane w wyniku funkcjonowania określonego przedsięwzięcia handlowego, bez względu na to, kto bezpośrednio zajmuje się interesami - właściciel czy osoby przez niego wyznaczone.

Podobnie zagadnienie przychodów z działalności morskiej określa Ulpianus:

Ulpianus libro vicensimo octavo ad edictum (D.14,1,1,15)

Exercitorem autem eum dicimus, ad quem obventiones et reditus omnes perveniunt, sive is dominus navis sit sive a domino navem per aversionem conduxit vel ad tempus vel in perpetuum.

Jak wynika ze źródła, zarządcą statku (exercitor navis) nazywany jest ten, komu przypadają w udziale zyski i dochody. Bez względu na to, czy byłby to właściciel statku, czy od właściciela za opłatą wziąłby statek w najem na czas oznaczony lub na stałe. Ulpianus używa dwóch określeń: obventiones - 'przypadkowy dochód', 'niestały zysk', 'profity', 'dochód z najmu statku’37, oraz reditus 'dochód', 'zysk', 'korzyść'38. Dwa określenia dochodu uzyskiwanego $z$ działalności statku wskazują być może na to, że rozróżniano stałe wpływy z działalności handlowej (reditus) i dodatkowe przychody (obventiones) wynikające $z$ działań, których nie można było zaplanować, jak np. zyski z zawarcia umowy locatio-conductio. W tekstach źródłowych pojawiają się też określenia vectura navium - 'fracht',

36 Zob. też D. 19,1,13,13 (Ulpianus). Zob. A. Berger, op.cit., s.v. quaestus; J. Sondel, op.cit., s.v. quaestus.

37 Zob. A. Berger, op.cit., s.v. obventiones; J. Sondel, op.cit., s.v. obventio.

38 Zob. A. Berger, op.cit., s.v. reditus; J. Sondel, op.cit., s.v. reditus. 
czyli opłaty za transport osób i towarów ${ }^{39}$, oraz merces - wynagrodzenie za usługę przewozu ${ }^{40}$. W źródłach nie ma więc jednolitego ujęcia dochodów i zysków osiąganych w wyniku prowadzenia działalności transportowej.

Mimo niejednolitości terminologicznych dochody tego typu mają jednak jedną cechę wspólną: wszystkie trafiały do majątku osoby zarządzającej statkiem. Jeżeli zyski $z$ działalności statku wpływały do zarządcy statku, a zarządcą został ustanowiony servus peculiaris, to dochody nie były częścią patrimonium, lecz powinny wejść w skład peculium ${ }^{41}$. W źródłach nie ma jednak żadnych informacji dotyczących prowadzenia rozliczeń związanych $z$ działalnością statku. Mogę więc jedynie założyć, że jeżeli statek funkcjonowałby w ramach peculium, to wpływy $z$ transportu osób i towarów stawałyby się częścią peculium i musiałyby zostać rozliczone w księdze rachunkowej peculium. Działalność handlowa była dziedziną wymagającą prowadzenia dokładnych rozliczeń, zwłaszcza w przewozie morskim. Prawnym właścicielem zysków $z$ działalności morskiej był właściciel niewolnika i statku (dominus navis), ale to servus peculiaris musiał prowadzić rozliczenia, skoro działał jako exercitor navis.

\section{Wnioski}

W źródłach dotyczących zarządzania statkiem nie ma informacji o tym w jaki sposób niewolnik uzyskiwał statek w celu prowadzenia interesów. Juryści piszą o powierzaniu majątku lub o ustanawianiu zarządu, ale nie o przekazywaniu statku. W wielu fragmentach pojawia się wyraźne traktowanie statku jako peculium: zarządcą statku jest servus peculiaris bądź servus vicarius, statek jest samo-

39 Zob. A. Berger, op.cit., s.v. vectura; J. Sondel, op.cit., s.v. vectura. Określenie to występuje m.in. w: D. 12,6,55 (Papinianus); D.5,3,29 (Ulpianus); D. 14,1,1,12 (Ulpianus); D.4,9,4,2. Zob. też: http://www.mcgill.ca/ maritimelaw/glossaries/maritime (dostęp: 3.12.2009 r.).

40 Np. D.4,9,5,pr. (Gaius). Zob. A. Berger, op.cit., s.v. merces; J. Sondel, op.cit., s.v. merces.

41 Zob. W.W. Buckland, op.cit., s. 174 i n.; J.-J. Aubert, op.cit., s. 60 i n.; J. Krzynówek, op.cit., s. 195 i n. 
dzielnie funkcjonującym przedsiębiorstwem niezależnym od patrimonium, a zaciąganie zobowiązań związanych $\mathrm{z}$ prowadzeniem działalności przewozowej mogło powodować odpowiedzialność de peculio. Sądzę, że właściciel statku wyodrębniał statek z patrimonium i przekazywał wykwalifikowanemu niewolnikowi w zarząd, gdyż umożliwiało to osiąganie większych zysków niż samodzielne radzenie sobie $z$ całością interesów. Sama kwestia prowadzenia rozliczeń, nie wspominając o odpowiedzialności, prawdopodobnie spowodowała połączenie peculium i statku w jedną formę aktywności handlowej. Myślę więc, że statek stawał się częścią peculium i funkcjonował jako działalność transportowa w jego ramach. Uważam, że przekazanie statku w ręce zarządcy odbywało się na ogólnych zasadach dotyczących peculium i $z$ tego względu nie wymagało wykształcenia dodatkowych pojęć, co by wyjaśniało brak określeń w źródłach dotyczących przekazania statku. Wystarczające były czynności typowe dla peculium. Dopiero zarząd statkiem jako specyficzna forma działalności handlowej różnił się od ogólnego zarządu peculium i dlatego w źródłach pojawia się więcej informacji dotyczących exercitio navis.

\section{SUMMARY}

\section{The ship as the peculium in classical Roman Law}

Classical Roman Law sources contain information about the ship managed by the servus peculiaris. Although there are many jurists' opinions about conducting seaborne business by the servus peculiaris, there are none regarding the obtaining of the ship. How the ship was transferred to the slave? Was the maritime business the whole peculium or just a part of it? Servus peculiaris was acting as the exercitor navis, this means that rules regarding the appointment of the captain (preapositio) cannot be applied. What rules should apply to the ship if it was administered as the peculium? The aim of this paper is to provide the answers to those questions.

Keywords: peculium, the ship, exercitio navis, Roman Law 


\title{
GLOSY I RECENZJE
}

\author{
COMMENTS AND REVIEWS
}


(c) $)(1) \ominus$ 